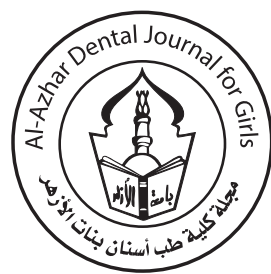

\title{
Effect of Reinforcement of Denture Base Resin with Zirconia on Bacterial Colonization and Some Mechanical Properties
}

\author{
Marwa M. Ebida ${ }^{1 *}$, Dina M. Kholief ${ }^{2}$, Shereen M. Kabeel ${ }^{3}$
}

Codex : 46/1904

azhardentj@azhar.edu.eg

http://adjg.journals.ekb.eg

DOI: $10.21608 /$ adjg.2019.5668.1017

\begin{abstract}
Purpose: The aim of the study was to compare between zirconia reinforced acrylic resins with that conventional acrylic resins (PMMA) regarding bacterial colonization and some mechanical properties (flexural strength, surface roughness, and surface hardness). Material and methods: Clinical study: sixteen completely edentulous patients were randomly selected which their ages ranged from 50-60 years. Patients were divided into two groups. Patients in the first group received maxillary and mandibular complete denture made of PMMA (Group I) and patients in the second group received maxillary and mandibular complete denture made of $\mathrm{ZrO}_{2}$ reinforced acrylic resins (Group II). Microbial biofilm was evaluated after three, six and nine months for each patient. Laboratory study: sixty specimens were constructed. The specimens were divided into two groups. Thirty specimens of PMMA (Group I) and thirty specimens of $\mathrm{ZrO}_{2}$ reinforced PMMA (Group II) for testing FS, surface hardness and surface roughness Results: The results of microbial biofilm evaluation in group II was significantly higher than that found in group I. The laboratory study results showed that FS and surface roughness in $\mathrm{ZrO}_{2}$ reinforced PMMA were significantly higher than conventional PMMA. Further, the study showed that an insignificant increase of surface hardness in $\mathrm{ZrO}_{2}$ reinforced PMMA when compared with conventional PMMA. Conclusion: Reinforcement of acrylic resin with $\mathrm{ZrO}_{2}$ in PMMA results in an increase of the microbial colonization and surface roughness of denture and improvement of some mechanical properties as flexural strength and surface hardness.
\end{abstract}

\section{INTRODUCTION}

Complete dentures are dental prosthesis that replaces the entire complete loss of natural teeth and its associated structures of the

mandible and the maxilla. The conventional complete denture is still
Zirconia, Microbial evaluation,

Flexural strength,

Surface hardness,

Surface roughness

* Paper extracted from Master thesis titled "Effect of Reinforcement of Denture Base Resin with Zirconia on Bacterial Colonization and Some Mechanical Properties”. email: marwa.masoud.me44@gmail.com

1. Demonstrator of Removable Prosthodontics, Faculty of Dental Medicine for Girls, Al-Azhar University.

2. Assist. Professor of Removable Prosthodontics, Faculty of Dental Medicine for Girls, Al-Azhar University.

3. Lecturer of Removable Prosthodontics, Faculty of Dental Medicine for Girls, Al-Azhar University. 
the treatment of choice for medical and financial reasons, although the increase usage of dental implants in the treatment of edentulous patients ${ }^{(1)}$.

The most widely used material for construction of denture base is heat cured polymethyl methacrylate (PMMA). It has several advantages such as it is non-toxic, non-irritant, not soluble in oral fluids, good aesthetical aspect, easy manipulation, and easy repair but its drawback are the weakness in its resistance, its high permeability, and presence of residual monomer ${ }^{(2)}$

$\mathrm{ZrO}_{2}$ is a hard white amorphous powder that is obtained from zirconium which is found naturally. It is produced by thermal processes. $\mathrm{ZrO}_{2}$ is a material that very resistance to crack propagation and It has premium mechanical properties with high strength , fracture toughness and high thermal expansion, so it is often the best material for joining ceramic and steel $^{(3)}$.

There are several approaches to improve the properties of acrylic resins. One of that methods is the addition of zirconia as a filler to PMMA as it is biocompatible, has high mechanical properties and has additional advantage of zirconia when is used as filler is superior esthetics. So, the $\mathrm{ZrO}_{2}$ powder has been chosen for improvement of properties of PMMA $^{(4-6)}$.

\section{MATERIAL AND METHODS}

The clinical study made on sixteen completely edentulous patients whose maxillary ridges covered with firm and healthy mucosa free from any signs of inflammation, ulceration, and flappy tissues. Patients with xerostomia or excessive salivation and Heavy smokers were excluded. All patients accepted this dental treatment and informed about the steps of this study and signed a written consent with the Research Ethics Committee (REC) approval. Dividing of sixteen patients into two groups eight patient for each one:
Group I: Each patient received maxillary and mandibular complete denture made of conventional heat cured acrylic resin. Group II: Each patient received maxillary and mandibular complete denture made of $\mathrm{ZrO}_{2}$ reinforced acrylic resin.

For each patient, Primary alginate impression for maxillary and mandibular arch were made using stock trays of suitable size then, a secondary impression was taken using zinc oxide and eugenol impression material, occlusion blocks were fabricated and centric relation in patient's mouth was recorded at the correct vertical dimension. Mounting of The maxillary and mandibular casts on a semi-adjustable articulator (Hanau articulator) and setting up of artificial teeth using cross-linked acrylic artificial teeth and waxing up was carried. The denture was tried in the patient mouth to check denture extension, retention, stability, tongue space, vertical dimension, and centric occluding relation. Flasking of the waxed up denture was done.

For Group I: processing of waxed-up upper and lower dentures into conventional heat cure acrylic resin by mixing powder of PMMA with monomer in a ratio of 2.7:1 then packing into mold space in the dough stage and for Group II: Waxed-up upper and lower dentures were processed into $\mathrm{ZrO}_{2}$ reinforced acrylic resin which is formed by adding $10 \mathrm{wt} \% \mathrm{ZrO}_{2}$ powder with an average particle size of 5-10 $\mu \mathrm{m}$ to PMMA. Mixing and blending were done to obtain a consistent and uniform mix by treating filler particles with $1 \mathrm{wt} \%$ of saline coupling agent before the mix and then mixing powder with the monomer in a ratio of 2.7:1 and packed in the dough stage into mold space. For both groups, trying the closes of flasks was done and flasks were clamped followed by Bench curing that done for $20 \mathrm{~min}$ and resin were processed in a $74^{\circ} \mathrm{C}$ water bath for eight hours and then the temperature was increased to $100^{\circ} \mathrm{C}$ for one hour. Curing, deflasking, finishing, and polishing was performed by a routine method. Finally, each patient delivered his denture and instruction were given to the patients for proper hygiene of the oral cavity, cleaning of the denture and follow up. 


\section{Microbial evaluation}

For clinical study sixteen samples were collected by swabbing the palatal mucosa and fitting surface of maxillary dentures after patients rinsed their mouth with tap water for both patients groups in sterile tubes containing $2 \mathrm{ml}$ normal saline after 3, 6 and 9 months from denture insertion. Samples were stored in a cold place (icebox) and transported to the laboratory within one hour.

The microbial evaluation was made through total colony forming unit and total counts of three standard strain organisms (C. albicans, S. mutants, lactobacilli) obtained from National Research Centre) NRC( culture collection.

Colony forming unit (CFU) was done through using conventional plate count agar. the sample was suspended in it which was incubated at $35 \pm 1^{\circ} \mathrm{C}$ for $48 \mathrm{~h}$, then $\mathrm{CFU}$ was enumerated and calculated per $\mathrm{ml}$ of sample.

$\mathrm{CFU} / \mathrm{ml}$ was calculated using the formula:

(no. of colonies $\times$ dilution factor)

volume of a culture plate

\section{Mechanical properties evaluation}

For laboratory study, a total of sixty specimens were constructed. According to the type of denture base resin the specimens were divided into two groups. According to sample dimensions and sort of test, each group was divided into three subgroups. Group I: Thirty specimens of conventional acrylic resin samples and Group II: Thirty specimens of zirconia reinforced acrylic resin samples for the flexural strength, surface hardness and surface roughness tests for both group. Sample preparation: the dimensions of rectangular metal dies for measuring flexural strength were $65 \mathrm{~mm}$ length $\times 10 \mathrm{~mm}$ width $\times 2.5 \mathrm{~mm}$ thickness. The dimensions of rectangular metal dies for measuring surface hardness and surface roughness were $30 \mathrm{~mm}$ length $\times 10 \mathrm{~mm}$ width $\times 2.5 \mathrm{~mm}$ thickness . Standardized specimens were prepared according to International Standards Organization (ISO)
Specification No. 1567 for heat cured acrylic resins and $\mathrm{ZrO}_{2}$ reinforced acrylic resins.

Flasking the metal dies using type III dental stone. The two halves of the flask were separated after setting of dental stone and the dies were removed from molds without distorting the mold space. Acrylic resins samples and $\mathrm{ZrO}_{2}$ reinforced acrylic resins samples were prepared as mentioned before and placed in the mold space to fabricate the test samples.

The flexural strength test of specimens were tested by using three-point bending test in Universal Testing Machine. A specimen was centrally loaded with a load cell of $5 \mathrm{KN}$ at a crosshead speed of $5 \mathrm{~mm} / \mathrm{min}$ over a two-point support span set at a distance of $20 \mathrm{~mm}$. Specimens were subjected to compression loading until fracture occurred. Flexural strength is the maximum load required for rupture that was recorded.

FS represents the limiting stress at which failure or instability is imminent. The value of the calculation of FS was guided by the formula:

$$
\sigma_{f} \frac{3 F L}{2 b d^{2}}
$$

Where; $\mathbf{F}$ is the maximum load, $\mathbf{L}$ is span, $\mathbf{b}$ is the specimen width and $\mathbf{d}$ is the specimen thickness.

Digital Display Vickers Micro-hardness Tester was used to determine surface Micro-hardness of the specimens with a Vickers diamond indenter and a 20X objective lens. The surface of the specimens was applied to a load of $200 \mathrm{~g}$ for 20 seconds. Three indentations, which were equally placed over a circle and separated from the adjacent indentations by $0.5 \mathrm{~mm}$, were made on the surface of each specimen.

USB Digital microscope with a built-in camera was used for photographed the surface roughness of Specimens that was connected with an IBM compatible personal computer using a fixed magnification of $120 X$. The resolution of images were $1280 \times 1024$ pixels per image. Microsoft office picture manager was cropped images to $350 \times 400$ pixels to specify/ standardize area of roughness measurement. 


\section{Statistical analysis}

All measurements were recorded and tabulated. Statistical analysis was then performed using a commercially available software program (SPSS 19; SPSS, Chicago, IL, USA). Data related to microorganisms count showed a parametric distribution. Therefore, both groups was compared by using independent t-test, parametric data of Flexure strength at Maximum Flexure load, surface hardness and surface roughness were compared using independent $t-$ test. The significant level was set at $\mathrm{P}<0.05$.

\section{RESULTS}

\section{Clinical study:}

1- Comparison of colony forming unit, Streptococcus_mutants (S. mutants) and lactobacilli between both groups

The mean value and standard deviation of CFU $\left(\mathrm{x} 10^{3}\right)$ in both groups are presented in table (1). At 3 months, a higher mean value was recorded in group
II $\left(\mathrm{ZrO}_{2}\right.$ reinforced acrylic resin PMMA) with no significance difference $(\mathrm{P}=0.22)$. While at 6 and 9 months, a higher mean value was recorded in group II $\left(\mathrm{ZrO}_{2}\right.$ reinforced acrylic resin PMMA) with an extremely significant difference $(\mathrm{P}=0.000)$ and $(\mathrm{P}=0.000)$ respectively.

The mean value and standard deviation of $\mathrm{S}$. mutants count in both groups presented in table (1). At 3,6 and 9 months, a higher mean value was recorded in group II $\left(\mathrm{ZrO}_{2}\right.$ reinforced acrylic resin PMMA)than group I , with a significant difference between groups $(\mathrm{P}=0.011),(\mathrm{P}=0.012)$ and $(\mathrm{P}=0.000)$ respectively.

The mean value and standard deviation of Lactobacilli count in both groups presented in table (1).At 3, 6 and 9 months, a higher mean value was recorded in group II ( $\mathrm{ZrO}_{2}$ reinforced acrylic resins PMMA), with a significance difference $(\mathrm{P}=0.028)$, a highly significant difference $(\mathrm{P}=0.0003)$ and an extremely significant difference $(\mathrm{P}=0.000)$ respectively.

Table (1): Comparison of mean values and standard deviation of $\mathrm{CFU}\left(x 10^{3}\right)$, S. mutants and lactobacilli between groups (independent $t$-test)

\begin{tabular}{|c|c|c|c|c|c|c|}
\hline C.F.U & Times & Groups & Mean & Std. Dev. & $\mathrm{T}$ & $\mathrm{P}$ \\
\hline & \multirow{2}{*}{3 months } & Group I & 147.39 & 18.42 & \multirow{2}{*}{0.5} & \multirow{2}{*}{$0.22 \mathrm{~ns}$} \\
\hline & & Group II & 154.44 & 15.45 & & \\
\hline & \multirow{2}{*}{6 months } & Group I & 154.78 & 20.70 & \multirow{2}{*}{5.56} & \multirow{2}{*}{$0.000 *$} \\
\hline & & Group II & 212.00 & 38.41 & & \\
\hline & \multirow{2}{*}{9 months } & Group I & 161.7 & 30.67 & \multirow{2}{*}{7.02} & \multirow{2}{*}{$0.000 *$} \\
\hline & & Group II & 231.89 & 29.29 & & \\
\hline \multicolumn{7}{|c|}{ S.mutans } \\
\hline & \multirow{2}{*}{3 months } & Group I & 40.56 & 12.08 & \multirow{2}{*}{2.69} & \multirow{2}{*}{$0.011 *$} \\
\hline & & Group II & 53.33 & 16.12 & & \\
\hline & \multirow{2}{*}{6 months } & Group I & 56.11 & 16.92 & \multirow{2}{*}{2.67} & \multirow{2}{*}{$0.012 *$} \\
\hline & & Group II & 70.56 & 15.52 & & \\
\hline & \multirow{2}{*}{9 months } & Group I & 82.78 & 20.62 & \multirow{2}{*}{6.05} & \multirow{2}{*}{$0.000 *$} \\
\hline & & Group II & 130.6 & 26.46 & & \\
\hline \multicolumn{7}{|c|}{ Lactobacilli } \\
\hline & \multirow{2}{*}{3 months } & Group I & 368.89 & 114.24 & \multirow{2}{*}{2.3} & \multirow{2}{*}{$0.028 *$} \\
\hline & & Group II & 440.00 & 63.99 & & \\
\hline & \multirow{2}{*}{6 months } & Group I & 621.94 & 210.59 & \multirow{2}{*}{4.04} & \multirow{2}{*}{$0.0003 *$} \\
\hline & & Group II & 960.56 & 286.28 & & \\
\hline & \multirow{2}{*}{9 months } & Group I & 999.44 & 340.75 & \multirow{2}{*}{6.99} & \multirow{2}{*}{$0.000 *$} \\
\hline & & Group II & 1625.78 & 168.52 & & \\
\hline
\end{tabular}

Significance level $p<0.05, *$ significant, $n s=$ non-significant 


\section{2- Comparison of Candida albicans between both groups}

The mean value and standard deviation of $\mathrm{C}$. Albicans count in both groups are presented in table (2) At 3 months, a higher mean value was recorded in group II , with no significant variation between both groups $(\mathrm{P}=0.14)$. While, at 6 months, a higher mean value was recorded in group II, with a considerable variation between both groups $(\mathrm{P}=0.043)$.At 9 months, a higher mean value was recorded in group II, with an extremely significant variation between both groups $(\mathrm{P}=0.000)$.

Table (2): Comparison of mean values and standard deviation of $C$. albicans count between group I and group II (independent t-test)

\begin{tabular}{|c|c|c|c|c|c|}
\hline Times & Groups & Mean & Std. Dev. & $\mathrm{T}$ & $\mathrm{P}$ \\
\hline \multirow{2}{*}{3 months } & Group I & 12.78 & 3.08 & \multirow{2}{*}{1.51} & \multirow{2}{*}{$0.14^{\mathrm{ns}}$} \\
\cline { 2 - 5 } & Group II & 14.56 & 3.94 & & \\
\hline \multirow{2}{*}{6 months } & Group I & 16.94 & 4.06 & \multirow{2}{*}{2.12} & \multirow{2}{*}{$0.043^{*}$} \\
\cline { 2 - 5 } & Group II & 20.00 & 4.64 & & \\
\hline \multirow{2}{*}{ 9 months } & Group I & 22.22 & 6.74 & \multirow{2}{*}{6.44} & $0.000^{*}$ \\
\cline { 2 - 5 } & Group II & 38.89 & 8.67 & & \\
\hline
\end{tabular}

Significance level $p<0.05, *$ significant, $n s=$ non-significant

\section{Laboratory study:}

\section{A- Flexure strength at Maximum Flexure load (MPa)}

Comparison of Flexure strength at Maximum Flexure load (MPa) in both subgroup IA (conventional heat-cured acrylic resin samples) and subgroup IIA $\left(\mathrm{ZrO}_{2}\right.$ reinforced acrylic resin samples) was presented in Table (3). A higher mean value of Flexure strength was recorded in subgroup IIA. Independent $\mathrm{t}$-test detected that this variation was statistically significant $(\mathrm{p}=0.033)$.

Table (3): Comparison of Flexure strength at Maximum Flexure load (MPa) in subgroups IA and IIA (independent t-test).

\begin{tabular}{|c|c|c|c|c|c|}
\hline Subgroups & Mean & $\begin{array}{r}\text { Std. } \\
\text { Dev. }\end{array}$ & $\begin{array}{c}\text { Std. Error } \\
\text { Mean }\end{array}$ & T & P \\
\hline Subgroup IA & 60.368 & 5.91 & 2.642 & \multirow{2}{*}{2.32} & $0.033^{*}$ \\
\hline Subgroup IIA & 66.376 & 5.73 & 4.801 & & \\
\hline
\end{tabular}

Significance level $P<0.05$, *significant

\section{B- Surface hardness and surface roughness}

Comparison of surface hardness in both subgroups IB (conventional heat-cured acrylic resin samples) and IIB $\left(\mathrm{ZrO}_{2}\right.$ reinforced acrylic resin samples) was presented in Table (4). A higher mean value and standard deviation of surface hardness were recorded in subgroup IIB. Independent t-test detected that this variation was not statistically significant $(\mathrm{p}=0.69)$.

Comparison of surface roughness in both subgroups IC (conventional heat-cured acrylic resin samples) and IIC ( $\mathrm{ZrO}_{2}$ reinforced acrylic resin samples) that was measured in micron was presented in Table (4). A higher mean value of surface roughness was recorded in subgroup IIC. Independent t-test detected that this variation was statistically significant ( $\mathrm{p}=0.008)$.

Table (4): Comparison of surface hardness and surface roughness in both subgroup IB and IIB and subgroup IC and subgroup IIC (independent t-test).

\begin{tabular}{|c|c|c|c|c|c|c|c|c|}
\hline Surface hardnes & & & & & & & & \\
\hline \multirow{2}{*}{ Subgroups } & \multirow{2}{*}{ Mean } & \multirow{2}{*}{ Std. Dev. } & \multirow{2}{*}{$\begin{array}{c}\text { Std. Error } \\
\text { Mean }\end{array}$} & \multirow{2}{*}{$\begin{array}{c}\text { Mean } \\
\text { difference }\end{array}$} & \multicolumn{2}{|c|}{ 95\% Confidence Interval of the Difference } & \multirow{2}{*}{$\mathrm{T}$} & \multirow{2}{*}{$P$} \\
\hline & & & & & Lower bound & Upper bound & & \\
\hline Subgroup IB & 41.291 & 3.020 & 0.780 & \multirow{2}{*}{-0.623} & \multirow{2}{*}{-3.85} & \multirow{2}{*}{2.60} & \multirow{2}{*}{0.40} & \multirow{2}{*}{$0.69^{\mathrm{ns}}$} \\
\hline Subgroup IIB & 41.914 & 5.217 & 1.347 & & & & & \\
\hline \multicolumn{9}{|l|}{ Surface roughness } \\
\hline Subgroup IC & 0.253 & 0.001 & 0.000 & \multirow{2}{*}{0.0015} & \multirow{2}{*}{-.006} & \multirow{2}{*}{0.0019} & \multirow[b]{2}{*}{3} & \multirow{2}{*}{$0.008^{*}$} \\
\hline Subgroup IIC & 0.256 & 0.003 & 0.001 & & & & & \\
\hline
\end{tabular}

Significance level $P<0.05$, *significant 


\section{DISCUSSION}

This study was designed as a prospective comparative clinical and laboratory trials. The success or failure of an oral prosthesis depends upon several factors including the technical and planning skills of the prosthodontics, properties of the material used and the health and tolerance of oral tissues ${ }^{(7)}$.

In the present study, the edentulous maxillary ridge were selected rather than the mandibular ridges, since, the amount of mucosa in contact with denture is generally greater than in mandible, and due to excessive saliva in the floor of the mouth which implies that the maxillary denture usually possess great clinical importance for detection of bacterial colonization $^{(8)}$.

The edentulous ridge had normal morphology and cover with firm healthy mucosa to ensure favorable conditions for prosthetic procedures and patient had no oral lesions when examined ${ }^{(9)}$.

There was a critical increase in the total count of microorganisms in group II (upper $\mathrm{ZrO}_{2}$ reinforced PMMA denture) during the follow-up periods when compared to group I (upper conventional PMMA denture) in this study.

This study had proved that both the nature of the denture base and its roughness, have a high effect on the degree of microbial colonization of the material. The count of adherent organisms after 3 months was significantly higher on group II than on the group I and also, increasing surface roughness leaded to increase microbial colonization for both types of acrylic ${ }^{(10)}$.

High microbial colonization was found in group II may be due to the high surface energy of the particle of $\mathrm{ZrO}_{2}$, this finding was in agreement with another study who demonstrated that Surface free energy (SFE) is a contributing factor which affects microbial adhesion and plaque maturation on surfaces ${ }^{(11)}$.
This study showed that surface roughness in group II ( $\mathrm{ZrO}_{2}$ reinforced PMMA) was significantly higher than group I (conventional PMMA). The surface roughness of denture material is critical factor as it affects the oral health of tissues that was in direct contact with the fitting surface of dentures ${ }^{(12)}$.

This result was in agreement with another study who showed that surface roughness is a very important factor that affecting microbial colonization on denture as rougher surfaces had more microorganism count than on the smoother surfaces ${ }^{(13)}$.

The results of this study showed that flexural strength of subgroup IIA $\left(\mathrm{ZrO}_{2}\right.$ reinforced acrylic resin) was significantly higher when compared to subgroup IA (Conventional heat cured acrylic resin). This result was in agreement with another study who showed that significant improvements in the mechanical properties with reinforcement of oxide particles ${ }^{(5)}$.

The results are also in agreement with previous studies that revealed that the fractures of the denture can be reduced by increasing the strength of PMMA through addition of $\mathrm{ZrO}_{2}$. The addition of zirconia in various dental materials was found to have significant improvement on the mechanical properties $^{(4,13)}$.

The finding of the present study may be explained on the basis that $\mathrm{ZrO}_{2}$ powder was added to PMMA in concentrations of $10 \%$ after treating with the saline coupling agent that provide excellent chemical bond between $\mathrm{ZrO}_{2}$ and acrylic resin. Using of zirconia as filler particles of size 5-10 $\mu \mathrm{m}$ helps in filling the interstitial matrix space of PMMA. The flexural strength increasing may result from filling of interstitial space of an acrylic resin matrix with $\mathrm{ZrO}_{2}$ that made interruption of crack propagation ${ }^{(5,6)}$.

On the other hand, another study showed that a slight decrease in flexural strength which may be explained on the basis of clustering the particles 
within the resin that leading to weakness of the material $^{(14)}$.

The results of this study revealed that insignificant increase in surface hardness in subgroup IIB $\left(\mathrm{ZrO}_{2}\right.$ reinforced PMMA samples) when compared with subgroup IB (conventional PMMA samples). This is finding is in agreement with the study who showed an insignificant increase in surface hardness of $\mathrm{ZrO}_{2}$ reinforced PMMA when compared with conventional PMMA ${ }^{(4)}$. Further, another studies showed that the addition of $\mathrm{ZrO}_{2}$ to PMMA leaded to significant increase of fracture toughness, impact strength and surface hardness of PMMA ${ }^{(15,16)}$.

This study showed that surface roughness in subgroup IIC $\left(\mathrm{ZrO}_{2}\right.$ reinforced PMMA) was significantly higher when compared to group IC (conventional PMMA). This may result from void formation from entrapped air and moisture, incomplete wetting of the fillers by the resin due to increasing fillers content. Furthermore, $\mathrm{ZrO}_{2}$ affects the integrity of the polymer matrix as it acts as an interfering factor ${ }^{(17-19)}$.

\section{CONCLUSION}

It was concluded that:

I- Reinforcement of $\mathrm{ZrO}_{2}$ particles in PMMA results in an increase the microbial colonization and surface roughness of denture.

II- Reinforcement of $\mathrm{ZrO}_{2}$ particles in PMMA has critical role in the improvement of some mechanical properties as flexural strength and surface hardness.

\section{REFERENCES}

1. Carlsson GE, Omar R. The future of complete dentures in oral rehabilitation. A critical review. J Oral Rehabil 2010; 37:143-56.

2. Pereira-Cenci T, Delbelcury AA, Crielaard W, Ten Cate JM. Development of Candida-associated denture stomatitis. J Appl Oral Sci 2008; 16:86-91.
3. Mundhe K, Jain V, Pruthi G, Shah N. Clinical study to evaluate the wear of natural enamel antagonist to zirconia and metal ceramic crowns. J Prosthetic Dent 2015; 114:358-63.

4. Ayad N M, Badawi MF, Fatah AA. Effect of reinforcement of high-impact acrylic resin with zirconia on some physical and mechanical properties.J Rev Clín Pesq Odontol 2008; 4:145-51

5. Zuccari AG, Oshida Y, Moore BK. Part I: Reinforcement of acrylic resins for provisional fixed restorations. J Biomed Mater and Eng 1997; 7:327-43.

6. Panyayong W, Oshida Y, Andres CJ, Barco TM, Brown DT, Hovijitra S. Reinforcement of acrylic resins for provisional fixed restorations. Part III: effects of addition of Titania and zirconia mixtures on some mechanical and physical properties. J Bio-med Mater and Eng 2002; 12:353-66.

7. Helmy SA. Laboratory evaluation of thermos-elastic heat cured acrylic resins with different softener/hardener ratios in both hard and elastic conditions. MD Thesis: University of Alexandria, 2013:1-73.

8. Myatt GJ, Hunt SA, Barlow AP, Winston JL, Bordas A, El Maaytah M.A clinical study to assess the breath protection efficacy of denture adhesive. J Contemp Dent Pract 2002; $3: 1-9$.

9. Luis IR, Lenny TS, Patrick WN: The Effect of Using Custom or Stock Trays on the Accuracy of Gypsum Casts. Int J Prosthodont 1996; 9:367-73.

10. Fletcher M. Bacterial attachment in aquatic environments: Diversity of surfaces and adhesion strategies. Bacterial adhesion: molecular and ecological diversity Ed. New York: Wiley-Liss 1996; 19:1-24.

11. Quirynen M, Dierickx K, Van Steenberghe D. Effects of surface roughness and free energy on oral bacterial adhesion. In Handbook of Bacterial Adhesion. Humana Press, Totowa, NJ 2000; 91-102.

12. Bollenl CM, Lambrechts P, Quirynen M. Comparison of surface roughness of oral hard materials to the threshold surface roughness for bacterial plaque retention: a review of the literature. Dent Mater 1997; 13:258-69.

13. Radford DR, Sweet SP, Challacombe SJ, Walter JD. Adherence of Candida albicans to denture-base materials with different surface finishes. J Dent 1998; 26:577-83.

14. Al-Rais RY, Al-Nakkash WA, Al-Bakri AK. Filler reinforced acrylic denture base material. Part 2-Effect of 
water sorption on dimensional changes and transverse strength. J Baghdad Coll Dent 2005; 17:6-10.

15. Asar NV, Albayrak H, Korkmaz T, Turkyilmaz I. Influence of various metal oxides on mechanical and physical properties of heat-cured polymethyl methacrylate denture base resins. J Adv Prosthodont 2013; 5:241-7.

16. Franklin P, Wood DJ, Bubb NL. Reinforcement of poly (methyl methacrylate) denture base with glass flake. J Dent Mater 2005; 21:365-70.
17. Ellakwa AE, Morsy MA, El-Sheikh AM. Effect of aluminum oxide addition on the flexural strength and thermal diffusivity of heat-polymerized acrylic resin. J Prosthodont 2008; 17:439-44.

18. Jagger DC, Harrison A, Jandt KD. The reinforcement of dentures. J Oral Rehab 1999; 26:185-94.

19. Sehajpal SB. Effect of metal fillers on some physical properties of the acrylic resin. J Prosthet Dent 1989; 61:746-51. 